\title{
Kalsitonin Menurunkan Derajat Apoptosis Kondrosit Tulang Rawan Sendi dengan Gangguan Biomekanik Instabilitas
}

\author{
Calcitonin Decreases Apoptotic Index of Articular Cartilage Chondrocytes of Biomechanically \\ Unstable Joint
}

\author{
Edi Mustamsir
}

Laboratorium Ilmu Bedah Bagian Orthopaedi dan Traumatologi Rumah Sakit Umum Dr. Saiful Anwar Malang

\begin{abstract}
ABSTRAK
Kalsitonin, suatu obat anti resorptif yang selama ini banyak digunakan dalam terapi osteoporosis, terbukti dapat mengurangi turnover tulang subkondral yang meningkat pada osteoarthritis (OA), mengurangi derajat kerusakan tulang rawan sendi pada beberapa model OA dan merubah komposisi biokimia pada matriks tulang rawan sendi. Mekanisme kerja kalsitonin dalam terapi osteoarthritis belum sepenuhnya diketahui. Apoptosis kondrosit dikaitkan dengan deplesi dari matriks tulang rawan pada OA. Penelitian ini bertujuan meneliti efek Kalsitonin terhadap penurunan indeks apoptosis kondrosit pada sendi yang mengalami gangguan biomekanik. Sampel hewan coba kelinci dibagi dalam 3 kelompok, kelompok 1 dan 2 dilakukan perlakuan pemotongan ligamentun cruciatum anterior (ACLT) dan menisektomi untuk membuat instabilitas sendi lutut kiri dan setelah 24 jam perlakuan diberikan injeksi kalsitonin pada kelompok 1, sedangkan kelompok 2 diberikan injeksi normal saline selama 6 minggu, kelompok 3 (kontrol) dilakukan operasi sham. Setelah 6 minggu, sampel diambil dari tulang rawan sendi lutut bagian femur dan tibia untuk dilakukan pemeriksaan apoptosis. Gangguan biomekanik instabilitas meningkatkan apoptosis kondrosit dengan bermakna baik pada sisi femur $(\bar{X}=27)$ maupun tibia $(\bar{X}=32.2)$ dari sendi dibandingkan kontrol. Pemberian kalsitonin indeks apoptosis yang lebih rendah dengan bermakna baik pada sisi tibia $(p=0,005)$ maupun pada sisi femur $(p=0,02)$. Kalsitonin memiliki efek protektif terhadap tulang rawan sendi yang mengalami gangguan instabilitas sendi
\end{abstract}

Kata Kunci: Apoptosis, anterior cruciate ligament (ACLT), instabilitas biomekanik, kalsitonin, menisektomi

\begin{abstract}
There are in vivo and in vitro experimental evidences that calsitonin, an anti resorptive agent that widely used for osteoporosis treatment, acts on both cartilage and subchondral bone by decreasing the enhanced turnover of the osteoarthritis (OA) subchondral bone, reducing the severity of cartilage OA lesions and altering the biochemical composition of the OA cartilage matrix. The exact mechanisms of how calcitonin works in OA treatment are not fully understood. Chondrocytes apoptosis has been associated with cartilage matrix depletion in OA. The aim of this study is to investigate the effect of calcitonin on decreasing chondrocyte apoptosis in biomechanically unstable joint. Rabbits were divided into 3 groups. Left knee instability was created by sectioning the anterior cruciate ligament (ACLT) and meniscectomy on group 1 and group 2. Group 1 and group 2 were treated with daily injection of salmon calcitonin and normal saline (placebo) respectively for 6 weeks. Sham operation was performed on group 3 as control group. After 6 weeks, all the animals were sacrificed and cartilages were harvested from both femoral and tibial side of knee joint for apoptosis examination. Mechanical instability increased chondrocyte apoptosis significantly on both femoral and tibial side of the joint $(p<0,05)$. Calcitonin significantly reduced apoptotic index on both tibia $(p=0,005)$ and femoral $(p=0,02)$ side of the joint. Calcitonin has chondroprotective effect by reducing apoptotic index in biomechanically unstable joint.
\end{abstract}

Keywords: Apoptosis, anterior cruciate ligament (ACLT), biomechanical instability, calcitonin, meniscectomy

Jurnal Kedokteran Brawijaya, Vol. 26, No. 3, Februari 2011; Korespondensi: Edi Mustamsir. Laboratorium Ilmu Bedah Bagian Orthopaedi dan Traumatologi, Rumah Sakit Umum Dr. Saiful Anwar Malang, Jl. Jaksa Agung Suprapto No. 2 Malang, Tel. (0341) 362101-362102 Email:edimustamsir@yahoo.co.id 


\section{PENDAHULUAN}

Osteoarthritis (OA) adalah penyakit sendi yang paling banyak dijumpai pada kelompok usia menengah dan lanjut $(1,2)$. Osteoarthritis ditandai dengan adanya nyeri sendi dan gangguan fungsi pada sendi yang terkena, dan pada tahap lanjut akan disertai dengan kontraktur sendi, atrofi otot dan deformitas dari ekstremitas. Nyeri sendi dan gangguan fungsi sendi disebabkan oleh degenerasi sendi yaitu suatu proses hilangnya tulang rawan sendi secara progresif yang disertai oleh upaya untuk perbaikan tulang rawan sendi, remodeling, sklerosis dari tulang subkondral dan pembentukan osteofit. Patofisiologi dari degenerasi sendi yang kemudian menimbulkan sindroma klinis dari osteoarthritis belum sepenuhnya diketahui (3). Hingga saat ini tatalaksana dari osteoarthritis adalah simtomatis untuk mengurangi rasa nyeri dan memperbaiki fungsi sendi. Belum ada terapi yang diterima secara penuh yang dianggap dapat merubah perjalanan penyakit dari osteoarthritis. Penelitian klinis dan eksperimental menunjukkan bahwa integritas struktural dari tulang rawan sendi tergantung pada turnover tulang subkondral yang normal, fungsi kondrosit yang baik dan beban biomekanik yang normal. Karena terdapat hubungan yang erat antara tulang subkondral dengan tulang rawan sendi, maka terapi yang ideal seharusnya dapat meregulasi baik aktivitas dari kondrosit maupun tulang subkondral (4-6).

Kalsitonin adalah obat anti resorptif yang telah lama digunakan untuk terapi osteoporosis dan saat ini penggunaan kalsitonin untuk OA mulai dipertimbangkan karena adanya temuan akan efek positif kalsitonin dalam terapi osteoarthritis $(6,7,8)$. Kalsitonin bekerja baik pada tulang rawan sendi maupun tulang subchondral. Kalsitonin terbukti dapat mengurangi turnover tulang subchondral yang meningkat pada osteoarthritis, mengurangi derajat kerusakan tulang rawan sendi pada beberapa model osteoarthritis dan merubah komposisi biokimia pada matriks tulang rawan sendi $(6,7,8)$. Pada penelitian in vitro, kalsitonin terbukti dapat merangsang sintesis proteoglycan dan kolagen tipe II, disamping itu kalsitonin juga dapat menghambt degradasi tulang rawan sendi melalui penghambatan aktivitas metalloprotease $(8,9)$. Selain itu, kalsitonin terbukti memiliki efek analgesik yang dilaporkan lebih kuat dibandingkan naproxen dalam mengurangi nyeri pada osteoarthritis sendi lutut $(7,10)$. Pada penelitian klinis, pasien OA yang mendapatkan terapi kalsitonin oral, menunjukkan adanya penurunan yang signifikan dari penanda untuk resorpsi tulang $C$ terminal telopeptides of collagen type I (CTX-1) dan penanda untuk resorpsi tulang rawan yaitu $C$-terminal telopeptides of collagen type II (CTX-II) (11).

Adanya temuan bahwa obat anti resorptif seperti kalsitonin dapat menghambat progresi dari OA menimbulkan pertanyaan apakah OA merupakan suatu penyakit pada tulang atau pada tulang rawan. Hingga saat ini belum ada cukup bukti yang menunjukkan apakah tulang atau tulang rawan yang merupakan sumber awal terjadinya OA. Tampaknya lebih tepat bila OA dianggap sebagai penyakit pada sendi sebagai satu kesatuan, dengan kondisi patologis yang tidak hanya terjadi pada tulang dan tulang rawan namun juga pada synovium, otototot periarticuler, ligamen dan meniscus (12).
Berkurangnya jumlah kondrosit secara bertahap pada OA berkaitan dengan nekrosis dan apoptosis (13). Bukti penelitian yang ada menunjukkan bahwa apoptosis kondrosit berhubungan dengan deplesi dari matriks, hal ini menyokong adanya peranan kerusakan sel pada fenomena ini $(14,15)$. Interleukin 1 (IL-1), Tumor Necrosis Factor- $\alpha$ (TNF- $\alpha$ ) dan nitric oxide terbukti memicu terjadinya apoptosis pada kultur kondrosit (16).

Semua temuan di atas menimbulkan pertanyaan apakah efek protektif kalsitonin pada tulang rawan sendi berhubungan dengan menurunnya indeks apoptosis kondrosit. Pemahaman akan mekanisme kerja obat anti resorbsi seperti kalsitonin dalam penatalaksanaan OA sangat diperlukan dalam rangka mengungkap lebih jauh penatalaksanaan OA yang lebih rasional, lebih efektif dan mungkin akan dapat menjadi salah satu pilihan terapi yang dapat digunakan dalam penatalaksanaan OA yang sedemikian kompleks ini. Tujuan penelitian ini membuktikan bahwa pemberian kalsitonin dapat menurunkan derajat apoptosis tulang rawan sendi yang mengalami gangguan biomekanik instabilitas dan membuktikan bahwa gangguan biomekanik instabilitas berpengaruh terhadap apoptosis tulang rawan sendi.

\section{METODE}

\section{Perlakuan Hewan Coba}

Penelitian yang digunakan dengan cara eksperimental dengan memakai kelinci sebagai hewan coba jenis New Zealand (Oryctolagus cuniculus), jantan, dengan umur dan berat badan yang tidak jauh berbeda. Kelinci dengan masa pertumbuhan tulang dewasa, yaitu diatas 2 bulan. dan dibagi atas 3 kelompok. Kelompok 1 dan 2 mendapat perlakuan berupa gangguan biomekanik sendi, yaitu instabilitas sendi yang dibuat dengan cara memotong ligamen cruciatum anterior (anterior cruciate ligament /ACL) dan pengangkatan meniskus medial (medial meniscectomy) pada lutut belakang kiri hewan coba, sedangkan kelompok 3 (kontrol) tanpa perlakuan yaitu dengan melakukan operasi membuka sendi dan menjahit kembali (Sham operation). Semua tindakan pada hewan coba dilakukan dengan pembiusan umum. Kelompok 1 mendapatkan injeksi intramuskuler 7 unit kalsitoninsalmon setiap hari sedangkan kelompok 2 mendapatkan injeksi intramuskuler normal saline (plasebo), setelah 6 minggu masing-masing kelompok diambil sampel tulang rawan sendi bagian femur dan tibia dan dilakukan pemeriksaan apoptosis dengan pengecatan imunohistokimia metode TUNEL.

\section{Pemeriksaan Histomorfologi dan Pengecatan Hematoxilin $\operatorname{Eosin}(H E)$}

Dilakukan dekalsifikasi tulang femur dan tibia dengan asam sitrat $10 \%$ selama $3 \times 24$ jam. Tulang dipotong longitudinal dan dimasukkan dalam blok parafin selama 24 jam. Dibuat dua sediaan, satu sediaan diwarnai dengan pengecatan HE dan satu sediaan lagi disiapkan untuk pengecatan imunohistokimia

Pemeriksaan Apoptosis Metode Imunohistokimia dengan Teknik Fragmentasi DNA (TUNEL)

Sediaan dicuci dengan phosphate buffered saline (PBS) pH 7,4 . Kemudian diinkubasi dengan proteinase-K $20 \mathrm{ug} / \mathrm{ml}$ 
selama 15 menit pada suhu $37^{\circ} \mathrm{C}$ dan dicuci dengan PBS pada $\mathrm{pH}$ 7,4 sebanyak tiga kali, masing-masing selama 5 menit. Kemudian diinkubasi dalam $\mathrm{H}_{2} \mathrm{O}_{2} 3 \%$ selama 15 menit. Setelah itu slide diinkubasi dengan Tunel fragmented DNA labelling selama 60 menit pada suhu $37^{\circ} \mathrm{C}$. Setelah dicuci dengan PBS, diinkubasikan dalam larutan peroksidase selama 40 menit pada suhu $37^{\circ} \mathrm{C}$ dan ditetesi dengan substrat untuk peroksidase (DAB-Diamino Benzidine) selama 20 menit pada suhu ruang. Kemudian slide dicuci dengan PBS pH 7,4 dan dilakukan counterstain dengan Mayer Hematoxilen selama 10 menit, dilanjutkan pembilasan dengan air kran dan pencucian dengan $\mathrm{dH} 2 \mathrm{O}$. Setelah dikeringkan dan ditutup dengan gelas penutup, maka apoptosis dapat diamati dengan mikroskop pembesaran 100 kali. Pembesaran yang digunakan untuk melihat apoptosis untuk mengidentifikasi sel yang mengalamai apoptosis memang digunakan pembesaran 1000 kali. Setelah diidentifikasi, untuk menghitung per lapang pandang jumlah sel yang mengalamai apotosis digunakan pembesaran 100 kali.

\section{HASIL}

Hasil penelitian disajikan secara kualitatif dan kuantitatif. Penyajian kualitatif dimaksudkan untuk memberikan gambaran apoptosis pada sel kondrosit di femur dan tibia (Gambar 1). Sel kondrosit yang mengalami apoptosis ditunjukkan dengan warna kecoklatan pada inti sel (tanda panah).
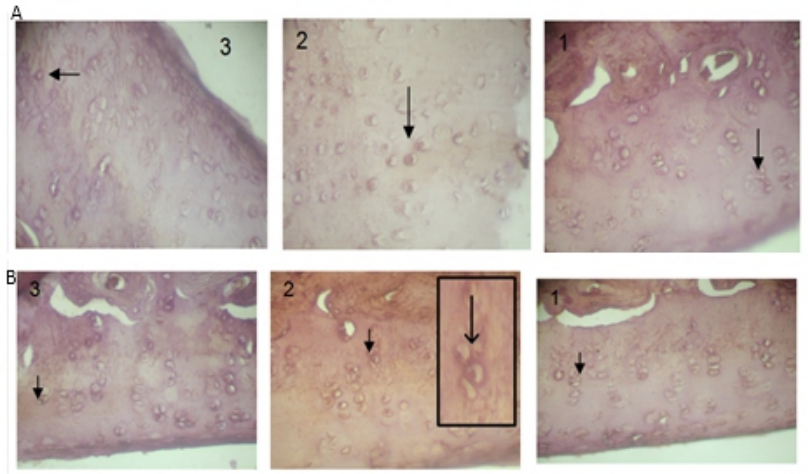

Gambar 1. Gambaran apoptosis tulang rawan sendi lutut dengan teknik fragmentasi DNA (TUNEL)

Keterangan: Pengecatan dengan counterstaining Mayer-Harris hematoxylene, pembesaran $100 x$.

A. Gambaran apoptosis tulang rawan sendi lutut bagian femur

B. Gambaran apoptosis tulang rawan sendi lutut bagian tibia

3. kelompok kontrol

2. kelompok dengan pemberian normal salin

1. kelompok dengan pemberian kalsitonin

Tanda panah menunjukkan sel kondrosit yang mengalami apoptosis.

Disamping gambaran apoptosis sel juga disajikan gambaran kerusakan tulang rawan berupa fisura secara histomorfologis pada lapisan superfisial tulang rawan (Gambar 2). Hasil menunjukkan gambaran morfologi lapisan superfisial yang lebih baik pada bagian femur maupun tibia pada kelompok yang diberikan kalsitonin (kelompok 1) dibandingkan dengan normal salin
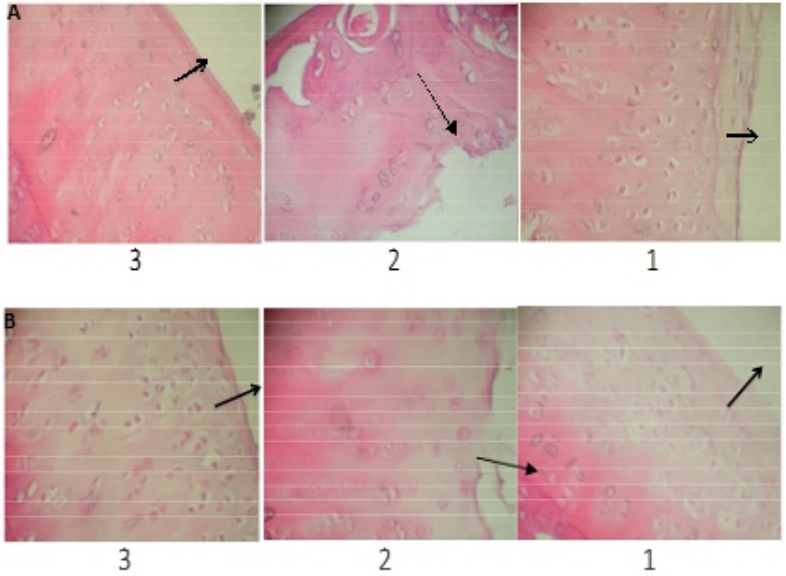

Gambar 2. Penampang histomorfologi tulang rawan sendi lutut dengan pengecatan $\mathrm{HE}$, pembesaran $100 \mathrm{x}$.

\section{Keterangan:}

A. Sediaan tulang rawan sendi lutut bagian tibia

B. Sediaan tulang rawan sendi lutut bagian femur

3. Kelompok kontrol

2. Kelompok dengan pemberian normal salin

1. Kelompok dengan pemberian kalsitonin.

Tanda panahmenunjukkan gambaran kerusakan tulang rawan berupa fisura pada lapisan superfisial tulang rawan sendi.

Secara kuantitatif disajikan penghitungan rerata apoptosis yang diambil dari sejumlah sampel tulang rawan bagian femur dan tibia (Tabel 1). Perlakuan ACLT dan menisektomi yang diberikan injeksi normal saline (kelompok 2 ) baik pada bagian femur $(x=27 ; p=0,002)$ maupun tibia $(x=32,2$; $p=0,02$ ) menunjukkan indeks apoptosis yang lebih tinggi secara bermakna dibandingkan kontrol. Hasil uji post hoc Tukey HSD menunjukkan pada kelompok dengan pemberian kalsitonin menunjukkan indeks apoptosis pada bagian femur yang tidak berbeda secara bermakna $(p=0,065)$ dibandingkan kontrol. Perbedaan indeks apoptosis yang bermakna ditemukan pada bagian tibia antara perlakuan kalsitonin dan kontrol $(p=0,001)$. Hal ini menunjukkan bahwa pemberian kalsitonin dapat memberikan perbaikan apoptosis hingga sama dengan kondisi normal pada bagian femur, namun pada bagian tibia meskipun lebih rendah namun belum sama dengan kondisi normal.

Tabel 1. Rerata indeks apoptosis sel kondrosit bagian femur dan tibia

\begin{tabular}{lccc}
\hline \multicolumn{1}{c}{ Kelompok Perlakuan } & Mean & Std. Deviation & N \\
\hline Bagian femur & & & \\
1. Transeksi ACL + Kalsitonin & $17,00^{2}$ & 5,523 & 5 \\
2. Transeksi ACL + Normal Saline & $27,00^{b}$ & 5,099 & 5 \\
3. Sham Operation (Kontrol) & $8,77^{\circ}$ & 1,000 & 3 \\
Bagian tibia & & & \\
4. Transeksi ACL + Kalsitonin & $21,20^{a}$ & 1,483 & 5 \\
5. Transeksi ACL + Normal Saline & $32,20^{b}$ & 6,458 & 5 \\
6. Sham Operation (Kontrol) & $5,67^{\mathrm{c}}$ & 0,577 & 3 \\
\hline
\end{tabular}

\section{Keterangan:}

${ }^{a, b, c}:$ notasi berbeda menunjukkan perbedaan signifikan

\section{DISKUSI}

Dari hasil penelitian ini didapatkan peningkatan apoptosis 
kondrosit dan kerusakan matriks tulang rawan sendi pada sendi yang mengalami gangguan instabilitas biomekanik . $\mathrm{Hal}$ ini sesuai dengan temuan sebelumnya yang menyatakan bahwa pada model eksperimen OA kelinci dengan transeksi $A C L$, kematian kondrosit karena apoptosis berhubungan dengan derajat kerusakan matriks $(14,15)$. Peranan rangsangan mekanik terhadap kondrosit telah banyak diteliti. Rangsangan mekanik yang dinamis terbukti bersifat anabolik terhadap kondrosit, sebaliknya rangsangan statis, dan sangat besar akan menghambat ekspresi gen aggrecan dan kolagen tipe II serta merangsang aktivitas dan ekspresi gen molekul katabolik seperti MMP-1, MMP-3, IL-1, TNF- $\alpha$ (17-19). Terdapat korelasi yang erat antara apoptosis kondrosit, produksi nitric oxide (NO) dan derajat keparahan degradasi matriks (14). Saat ini secara umum diakui bahwa sitokin proinflamasi seperti IL-1 dan TNF- $\alpha$ memainkan peranan penting dalam perubahan biokimia pada kondrosit dan tulang rawan. Salah satu mekanisme sitokin dalam menimbulkan efeknya adalah melalui produksi dari inducible NO synthase (iNOS) (20). Pemberian inhibitor iNOS terbukti dapat menurunkan kerusakan tulang rawan sendi dan apoptosis (21). Penelitian lain mengungkap adanya peran radikal bebas oksigen pada degradasi matriks dan apoptosis kondrosit setelah terjadinya gangguan biomekanik instabilitas (22).

Pemberian kalsitonin pada hewan coba yang telah mengalami transeksi $\mathrm{ACL}$ dan pemotongan meniscus (kelompok 1) ternyata menyebabkan penurunan apoptosis yang bermakna dibandingkan dengan tanpa pemberian kalsitonin baik pada femur maupun tibia. Beberapa penelitian sebelumnya baik in vitro maupun in vivo telah membuktikan bahwa kalsitonin memiliki efek protektif terhadap tulang rawan sendi $(6,7,8)$, dapat merangsang sintesis proteoglikan dan kolagen tipe II (23) dan mampu menghambat aktivitas kolagenase terhadap kolagen tipe II (24). Bagaimana mekanisme kerja kalsitonin pada osteoartritis belum sepenuhnya diketahui. Sondergaard menyatakan bahwa kalsitonin

\section{DAFTAR PUSTAKA}

1. Einhorn, TA, Buckwalter JA, and Simon SR. Orthopaedic Basic Science. 2nd edition. New York: American Academy of Orthopaedic Surgeons; 2000; p. $443-470$.

2. Brooks PM. Impact of Osteoarthritis on Individuals and Society: How Much Disability? Social Consequences and Health Economic Implications. Current Opinion in Rheumatology. 2002; 14(5): 573577.

3. Buckwalter JA, Saltzman C, and Brown T. The Impact of Osteoarthritis. Implication for Research. Clinical Orthopaedics and Related Research. 2004; 427 (Suppl): 6-15.

4. Felson DT. Risk Factors for Osteoarthritis; Understanding Joint Vulnerability. Clinical Orthopaedics and Related Research. 2004; 427 (Suppl): 16-21.

5. Hayami T, Pickarski M, Wesolowski GA, et al. The Role of Subchondral Bone Remodeling in Osteoarthritis: Reduction of Cartilage Degeneration and Prevention bekerja langsung pada kondrosit, terbukti dengan diekspresikannya reseptor kalsitonin pada kondrosit sapi (8). Penelitian lainnya menunjukkan bahwa kondrosit manusia tidak mengekspresikan reseptor kalsitonin dan diduga bahwa efek kondroprotektif kalsitonin mungkin terjadi secara tidak langsung melalui efek kalsitonin pada tulang subkondral (25).

Tulang rawan yang normal adalah jaringan yang tidak memiliki pembuluh darah dan saraf, namun pada OA terdapat microcrack, kanal vaskuler dan neovaskularisasi antara tulang subkondral dan tulang rawan sendi yang memungkinkan terjadinya transfer informasi humoral dari tulang subkondral ke lapisan basal tulang rawan sendi dan memodulasi metabolism kondrosit serta menginduksi terjadinya perubahan fenotip kondrosit (26-30).

Temuan adanya penurunan apoptosis setelah pemberian kalsitonin pada model OA hewan coba, juga menimbulkan pertanyaan lewat jalur sinyal mana kalsitonin bekerja. Selama ini kalsitonin lebih banyak digunakan untuk terapi osteoporosis dan penelitian sebelumnya lebih banyak terfokus pada efek kalsitonin pada tulang. Efek anti apoptosis kalsitonin terhadap osteoblast dan osteosit terbukti terjadi melalui jalur mitogen activated protein kinase (MAPK) seperti Erk-1/2, p38 kinase, JNK dan lainlain $(31,32)$. Pada penelitian lain tentang apoptosis kondrosit, ditemukan adanya peran yang saling berlawanan antara p38 kinase dan Erk-1/2 (20).

Pemberian kalsitonin dapat menurunkan apoptosis tulang rawan sendi yang mengalami gangguan biomekanik instabilitas. Gangguan biomekanik instabilitas berpengaruh terhadap apoptosis tulang rawan sendi. Dari penelitian ini jelas bahwa kalsitonin memiliki efek protektif terhadap kerusakan tulang rawan sendi pada model OA. Mekanisme kerja kalsitonin dalam menimbulkan efek tersebut seperti jalur sinyal mana yang dipakai, apakah efeknya langsung pada kondrosit atau tidak langsung melalui tulang subkondral, memerlukan penelitian lebih lanjut.

of Osteophyte Formation by Alendronate in the Rat Anterior Cruciate Ligament Resection Model. Arthritis and Rheumatism. 2004 ; 50(4): 1193-1206.

6. Karsdal MA, Tanko LB, Riis BJ, et al. Calcitonin is Involved in Cartilage Homeostasis: Is Calcitonin A Treatment for OA. Osteoarthritis and Cartilge. 2006; 14(7): 617-624.

7. Manicourt DH, Devogelaer JP, Azria M, Silverman S, et al. Rationale for the Potential Use of Calcitonin in Osteoarthritis. Journal Musculoskeletal and Neuronal Interaction. 2005 ; 5(3): 93-285.

8. Sondergaard BS, Wulf $\mathrm{H}$, Henriksen $\mathrm{K}$, et al. Calcitonin Directly Attenuates Collagen Type II Degradation by Inhibition of MMP Expression and Activity in Articular Chondrocytes. Osteoarthritis and Cartilage. 2006; 14(8): 759-768.

9. Hellio MP, Peschard MJ, Cohen C, et al. Calcitonin Inhibits Phospholipase A2 and Collagenase Activity of Human Osteoarthritic Chondrocytes. Osteoarthritis and Cartilage. 1997; 5(2): 121-128.

10. Badurski J, Jeziernicka E, Naruszewicz K, et al. 
Comparative Analysis of Three Treatment Regimens for Treating Gonarthritis with Kalsitonin, Naproxen and Flavonoids Based on EULAR Criteria and Visual Analogue Scale (VAS). Polski Tygodnik Lekarski. 1995; 50(44-47): 37-40.

11. Karsdal MA, Byrjalsen I, Henriksen $\mathrm{K}$, et al. The Effect of Oral Calcitonin Delivered with 5-CNAC on Bone and Cartilage Degradation in Osteoarthritic Patients: A 14-Day Randomized Study. Osteoarthritis and Cartilage. 2010; 18(2): 150-159.

12. Abramson SB, Attur M, Amin AR, and Clancy R. Nitric Oxide and Inflammatory Mediators in the Perpetuation of Osteoarthritis. Current Rheumatology Report. 2001; 3(6): 535-541.

13. Lotz M, Hashimoto S, and Kuhn K. Mechanisms of Chondrocyte Apoptosis. Osteoarthritis and Cartilage. 1999; 7(4): 389-391.

14. Hashimoto S, Takahashi K, Amiel D, Coutts RD, and Lotz M. Chondrocyte Apoptosis and Nitric Oxide Production During Experimentally Induced Osteoarthritis. Arthritis and Rheumatism. 1998; 41(7): 1266-1274.

15. Thomas CM, Fuller CJ, Whittles CE, and Sharif M. Chondrocyte Death by Apoptosis is Associated with Cartilage Matrix Degradation. Osteoarthritis and Cartilage. 2007; 15(1): 27-34.

16. Malemud CJ, Islam N, and Haqqi TM. Pathophysiologic Mechanisms in Osteoarthritis Lead to Novel Therapeutic Strategies. Cells Tissue Organs. 2003; 174(1-2): 34-48.

17. Millward-Sadler SJ, Wright MO, Davies LW, Nuki G, and Salter DM. Mechanotransduction via Integrins and Interleukin-4 Result in Altered Aggrecan and Matrix Metalloproteinase 3 Gene Expression in Normal, but Not Osteoarthritic, Human Articular Chondrocytes. Arthritis and Rheumatism. 2000; 43(9): 2091-2099.

18. Fitzgerald JB, Jin $M$, Dean $D$, et al. Mechanical Compression of Cartilage Explants Induces Multiple Time-Dependent Gene Expression Patterns and Involves Intracellular Calcium and Cyclic AMP. The Journal of Biological Chemistry. 2004; 279: 1950219511.

19. Murata M, Bonassar LJ, Wright $\mathrm{M}$, Mankin $\mathrm{HJ}$, and Towle CA. A Role for the Interleukin-1 Receptor in the Pathway Linking Static Mechanical Compression to Decreased Proteoglycan Synthesis in Surface Articular Cartilage. Archives of Biochemistry and Biophysics. 2003; 413(2): 229-235.

20. Kim SJ, Ju JW, Oh CD, et al. ERK-1/2 and p38 Kinase Oppositely Regulate Nitric Oxide-Induced Apoptosis in Chondrocytes in Association with p53, Caspace-3 and Differentiation Status. The Journal of Biological Chemistry. 2002; 277(2): 1332-1339.

21. Pelletier JP, Fernandes JC, Jovanovic DV, Reboul P, and
Pelletier JM. Chondrocyte Death in Experimental Osteoarthritis is Mediated by MEK $1 / 2$ and $p 38$ Pathways: Role of Cyclooxygenase-2 and Inducible Nitric Oxide Synthase. Journal of Rheumatology. 2001; 28: 19-2509.

22. Hidayat M. Stres Oksidatif sebagai Faktor Penyebab Dalam Patogenesis Degenerasi Tulang Rawan Sendi Osteoarthritis Sekunder Akibat Gangguan Biomekanik Instabilitas. [Disertasi]. Universitas Airlangga, Surabaya. 2003.

23. Sondergaard BS. Calcitonin Stimulates Proteoglycan and Collagen Type II Biosynthesis in Articular Cartilage Ex Vivo. Osteoarthritis Cartilage. 2005; 13(A): 142.

24. Hellio MP, Peschard MJ, Cohen C, Richard M, and Vignon E. Calcitonin Inhibits Phospholipase A2 and Collagenase Activity of Human Osteoarthritic Chondrocytes. Osteoarthritis Cartilage. 1997; 5: 121128.

25. Lin Z, Pavlos NJ, Wood DJ, Xu J, and Zheng $\mathrm{MH}$. Evidence that Human Cartilage and Chondrocytes do Not Express Calcitonin Receptor. Osteoarthritis Cartilage. 2008; 16: 57-450.

26. Sokoloff L. Microcrack in the Calcified Layer of Articular Cartilage. Archives of Pathology and Laboratory Medicine. 1993; 117(2): 191-195.

27. Westacott $\mathrm{Cl}$, Webb GR, Warnock MG, Sims JV, and Elson JV. Alteration of Cartilage Metabolism by Cells from Osteoarthritic Bone. Arthritis and Rheumatism. 1997; 40(7): 1282-1291.

28. Guevremont M, Martel-Pelltier J, and Massicotte F. Human Adult Chondrocytes Express Hepatocyte Growth Factor (HGF) Isoform but Not HGF: Potential Implication of Osteoblasts for The HGF Presence in Cartilage. Journal of Bone and Mineral Research. 2003; 18(6): 1073-1081.

29. Sanchez C, Deberg MA, Piccardi N, Msika P, Reginster JYL, and Henrotin YE. Subchondral Bone Osteoblasts Induca Phenotype Changes in Human Chondrocytes. Osteoarthritis and Cartilage. 2005; 13(11) : 988-997.

30. Prasadam I, Van Gennip S, Friis T, Shi W, Crawford R, and Xiao Y. ERK-1/2 and $p 38$ in the Regulation of Hypertrophic Changes of Normal Articular Cartilage Chondrocytes Induced by Osteoarthritic Subchondral Osteoblasts. Arthritis and Rheumatism. 2010; 62(5): 1349-1360.

31. Chen Y, Shyu JF, Santhanagopal A, et al. The Calcitonin Receptor Stimulates Shc Tyrosine Phosphorylation and ERK-1/2 Activation. The Journal of Biological Chemistry. 1998; 273: 19809-19816.

32. Plotkin LI, Weinstein RS, Parfitt AM, Robertson PK, Manolagas SC, and Bellido T. Prevention of Osteocyte and Osteoblast Apoptosis by Bisphosphonates and Calcitonin. The Journal of Clinical Investigation. 1999; 104: 1363-1374. 